\title{
Слово редактора
}

Це число «Українського релігієзнавства»є другим у 2019 році. Воно продовжує започатковану в цьогорічному першому числі вміщення статей за новими вимогами до їх змісту й технічного оформлення. Журнал-бюлетень виконаний у новій платформі OpenJournalSystem, включено до тих наукометричних баз, що відповідають глобальній індексації наукових публікацій (Google Scholar, Copernicus). Редакційній колегії, як і авторам, не вдалося поставити процес, як то кажуть, на потік, хоча все автоматизовано, і кожна подана стаття дається із великими труднощами. Автори при поданні своїх матеріалів не завжди враховують ці вимоги, чим уповільнюють процедуру прийняття статті до друку, а часто i відхиляються на початкових етапах. Тому настійно радимо кожному, хто бажає бути надрукованим у нашому часописі, ще раз ознайомитися 3 тими вимогами до оформлення статей і подання матеріалів на сайт журналу, які знаходяться за адресою:

https://uars.info/index.php/uars/about/submissions.

Виконуючи ці вимоги, ми долучимося до включення часопису у світовий науковий простір.

Тематично і персонально ми хочемо здолати наявну тенденцію вдатися до друку статей в УР лиш тих, хто прагне ним скористатися при захисті своїх дисертацій. Насамперед має йти мова про розвиток і збагачення релігієзнавчої науки у всіх іï дисциплінарних виявах. Нині ми маємо повноту вияву лише статей з історії релігії, її політології, правології, етнології. Дещо менше - 3 антропології, культурології і психології релігії. Практично відсутні статті з філософії релігії, ії соціології і географії. Часопис має засвідчити вихід україн- 
ського релігієзнавства у світовий науковий простір 3 нашого фаху. Тому всяк вітаються зарубіжні автори, яких ми плануємо залучити до наукових дискусій.

Варто ширше рекламувати через рецензії та анотації праці з фаху як індивідуальні, так і колективні. То ж редакція зацікавлена одержувати їх примірники з наступним коментарем. Цим певною мірою буде здолана не лише непоінформованість про наукові здобутки, а й та насиченість релігієзнавчими знаннями, яка вже наступила. Варто більше писати з проблем практичного релігієзнавства, залучати до автури й богословських релігієзнавців.

Редакція вдячна тим науковцям, яким прийшлося рецензувати статті першого і вже цього, другого числа часопису, завдяки яким ми в рубриці "Філософія релігіі" маємо статтю Тетяни Вікторівни Гаврилюк "Теологія втілення новітнє слово про свободу грецької православної думки", в якій авторка аналізує ключові питання теології сучасного грецького богослова Хрисостомоса Стамуліса, зокрема співвідношення любові Еросу та любові Агапе. Знання грецької мови, а відтак і власний переклад праць теолога надає авторці можливість найповніше розкрити його погляди на взаємозв' язок ключових антропологічних категорій християнства віри, любові та свободи, що є для сучасного православ'я надзвичайно актуальним, але й складним викликом.

Розділ "Історія релігіі" представлений статтею Олександра Сагана "Конституювання Православної Церкви України як чинник зміни культурно-цивілізаційної парадигми незалежної України". Запропонована відомим дослідником православ'я тема сьогодні у всіх на слуху, але фахова точка зору на внутріправославні процеси в Україні є не тільки експертною, а й інформативною, оскільки автор не тільки досліджує православ' я, але й тісно включений в події навколо ПЦУ. Важко не погодитися з автором в тому, що отримання православними віруючими України Томосу про визнання автокефалії і конституювання Православної Церкви України 


\section{Слово редактора}

(ПЦУ) позитивно впливає не лише на розвиток самого Православ'я, але й сприятиме українському поступу від азійської до європейської культурно-цивілізаційної моделі.

На розгляд читачів подана дискусійна стаття Оксани Горкуши "Громадська діяльність українських академічних релігієзнавців в останнє п'ятиріччя". В науко-вому середовищі фігурують дві точки зору щодо науковості в науці. Одна з них виступає за чисту науковість/ об'єктивність у дослідженнях релігієзнавців, які не мають маніфестувати свої конфесійні, громадянські чи партійні симпатії, ба більше - належності, а друга наполягає на неможливості наукового пошуку, його обмеженості поза чіткою суспільною орієнтацією, тим більше в часи політичних і гуманітарних криз чи катастроф. Запропонований матеріал демонструє, яким чином академічні релігієзнавці поєднують свою фахову компетенцію та громадську діяльність, як науково-пізнавальна активність доповнюється або проявляється в просвітницько-громадській. Авторка пропонує класифікувати громадську діяльність акад.мічних релігієзнавців за певними критеріями, що допоможе кращій самоідентифікації науковців.

Постійною плануємо зробити рубрику "Архіви. Джерела. Спогади". I не тому що назбиралося багато цікавого матеріалу про історію релігієзнавства в Україні, і не тому що старіють і йдуть з життя засновники новітнього українського релігіє-знавства, а тому що приходить молоде покоління, яке мало що знає (а хто їм про це розкаже) про перші кроки вітчиз-няної науки про релігію доби Незалежності. Саме тому до 25-літного ювілею УАР вирішено було зібрати спогади заснов-ників та активних членів асоціації, для чого активісти роз-робили Опитальник, розіславши всім, хто так чи інакше був причетний до створення цієї професійної спільноти. Отри-мано декілька матеріалів від провідних релігієзнавців-ветеранів України, публікацію яких ми розпочинаємо цим номером. На питання відповідаю і я, президент УАР, доктор філософських наук, професор Анатолій Миколайович Колодний. Всі опитані отримали 
однакові питання, подаючи свої власні спогади. Врахуймо, що від часу створення УАР пройшло понад чверть століття, щось могло забутися, щось викривитися в рцінках, але ці матеріали мають непересічне значення, оскільки оповідають про історію постання першого професійного об'єднання релігієзнавців в Україні, які сьогодні добре знані не тільки в Україні, але й за кордоном. Якщо в ваших пер-сональних архівах чи в пам'яті збереглися якісь документи, матеріали, фото, сторінки нашого журналу відкриті для вас.

Комусь може здатися, що ми вже все знаємо про релігію, про ті чи інші релігійні течії. Але життя щодня приносить якісь відкриття. Ось і вирішено відкрити нову рубрику "Знайомство з новою релігійною традицією".

Цього разу мова піде про діяльність і вчення послідовників мало відомого в Україні видатного турецького мислителя Саїда Нурсі. Після активізації у 2018-2019 рр. турецько-українських наукових зв'язків інтерес українських вчених до життя і творчості Саїда Нурсі значно зріс. Цим матеріалом - короткою біографією, яку написав кандидат історичних наук, ст. наук. співробітник Відділення релігієзнавства ІФ НАНУ І.А.Козловський, та інтерв'ю 3 послідовницею вчення мислителя, яке провела кандидат соціологічних наук доцент НаУКМА О.Богдан, ми хочемо привернути увагу до духовної спадщини турецького богослова i філософа не тільки вузьких спеціалістів, дослідників релігіі, але й широкого кола читачів.

Традиційний розділ журналу "Рецензіі" представлений матеріалом, який підготувала Л.Филипович про англомовну книгу "Церкви в українській кризі" ("Churches in the Ukrainian Crisis" edited by Andrii Krawchuk and Thomas Bremer. London: Palgrave Macmillan, 2016. 225 р. Незважаючи на те, що дослідження датується 2016 роком, воно не втратило своєї актуальності й досі, оскільки демонструє високий фаховий рівень розуміння релігійних процесів, які відбуваються в Україні. Нам важливо знати, що про це пишуть за- 


\section{Слово редактора}

кордонні науковці, щоб зрозуміти те, як сприймається релігійна Україна за іï межами, які там існують основні тренди, які ми може-мо не тільки знати, але й корегувати.

Остання інформація, яка подана в цьому номері журналу, стосується наукової конференції, яку проводить європейська наукова спільнота дослідників релігії в Чехії навесні 2020 р. Включайтеся в європейський науковий простір, беріть участь в таких заходах, представляйте релігієзнавчу Україну за кордоном. Переконаний, що ми маємо цікаві результати досліджень релігії, які можемо показати своїм колегам з Свропи.

Бажаю корисного і приємного читання, яке має надихнути всіх вас на співпрацю із виданням нових чисел нашого журналу.

Головний редактор Анатолій Колодний 